\title{
Fatal complications of adult paraesophageal hernia: A population- based study
}

Eero I. Sihvo, MD, PhD, ${ }^{a}$ Jarmo A. Salo, MD, PhD, ${ }^{a}$ Jari V. Räsänen, MD, PhD, ${ }^{a}$ and Tuomo K. Rantanen, $\mathrm{MD}, \mathrm{PhD}^{\mathrm{b}}$

Objectives: Data on mortality from paraesophageal hernia are scarce. This study focused on mortality associated with its natural history or conservative treatment.

Methods: For this population-based retrospective study, Finland's administrative databases provided preliminary data. Among 333 patients who died from benign esophageal diseases or hiatal hernias, analysis of medical records led us to include 32 .

Results: From 1987 through 2001 in Finnish hospitals, 563 patients underwent surgical intervention and 67 underwent conservative treatment for paraesophageal hernia. This hernia caused death (mortality, 0.6/1,000,000 of the adult population; $95 \%$ confidence interval, $0-1.8 / 1,000,000)$ in 32 patients, $29(91 \%)$ with concomitant diseases. The overall mortality rate for the 563 having surgical treatment was $2.7 \%$ ( 15 patients). Three died after elective repair. Of 67 patients hospitalized for symptomatic paraesophageal hernia and treated conservatively, 11 $(16.4 \%)$ died in the hospital within a mean of 42 months (range, 2-96 months) from onset of symptoms. Four $(13 \%)$ deaths might have been prevented by elective surgical intervention. Of the 32 deceased patients, 4 $(12.5 \%)$ had type II, $16(50 \%)$ had type III, and $9(28.1 \%)$ had type IV hiatal hernias. In $3(9.4 \%)$ patients type remained unknown. Death resulted from incarceration in $24(75 \%)$, complications of surgical intervention in $6(18.8 \%)$, and bleeding ulcer in $2(6.2 \%)$.

Conclusions: Overall, most deaths were related to type III or IV hernias in aged patients with concomitant diseases, with those with severe symptoms requiring hospitalization at significant risk. Except for those at high surgical risk, we recommend repair of the paraesophageal hernia, at least in symptomatic patients.

Earn CME credits at

http://cme.ctsnetjournals.org

Hiatal hernia associated with gastroesophageal reflux disease (GERD) is a common finding in general or gastroenterologic practice. ${ }^{1}$ The severity of GERD, estimated as esophageal mucosal damage, is related to the presence and size of type I, sliding, or axial hernias. ${ }^{2}$ Type II (true paraesophageal hernia), type III (mixed paraesophageal hernia), and type IV (giant hernia with thoracic displacement of the stomach and other intestinal contents) hernias account for $5 \%$ to $10 \%$ of all hiatal hernias. ${ }^{3,4}$ No reports exist of the fatal complications of paraesophageal hernias at the population level.

The annual incidence of acute symptoms in patients with paraesophageal hernias has a wide range, from $0.7 \%$ to $7 \%$ of patients. 5 The pooled annual probability of need for emergency surgery is estimated to be around $1 \%$, with a life-

\footnotetext{
From the Division of General Thoracic and Esophageal Surgery, Department of Cardiothoracic Surgery, ${ }^{\text {a }}$ Helsinki University Central Hospital, Helsinki, Finland, and the Department of Gastroenterology and Alimentary Tract Surgery, ${ }^{\mathrm{b}}$ Tampere University Hospital, Tampere, Finland.

Received for publication Jan 23, 2008; revisions received April 18, 2008; accepted for publication May 18, 2008.

Address for reprints: Jarmo A. Salo, MD, PhD, Division of General Thoracic and Esophageal Surgery, Department of Cardiothoracic Surgery, Helsinki University Central Hospital, PO Box 340, Haartmaninkatu 4, FIN-00029 HUS, Helsinki, Finland (E-mail: jarmo.salo@hus.fi).

J Thorac Cardiovasc Surg 2009;137:419-24

$0022-5223 / \$ 36.00$

Copyright $₫ 2009$ by The American Association for Thoracic Surgery doi:10.1016/j.jtcvs.2008.05.042
}

time risk of $18 \%$ at age 65 years. ${ }^{7}$ Patients with type II, III, or IV hernias might face such nonreflux complications as intrathoracic incarceration of the stomach, gastric volvulus, bleeding, perforation, or decreased pulmonary function. ${ }^{3,8-10}$ Complications of type I hiatal hernias are mainly related to the complications of severe GERD, such as hemorrhagic esophagitis, aspiration pneumonia, or esophageal perforation. ${ }^{11,12}$ Clinically, patients with complicated paraesophageal hernias have presented most commonly with varying degrees of gastric obstruction, hemorrhage from gastric ulcerations, respiratory embarrassment caused by a grossly compromised thoracic cavity, or perforation of an ulcer into adjacent organs. ${ }^{9,13-15}$ Their presenting symptoms can be vague or very uncommon, such as tension gastrothorax or heart failure. ${ }^{16,17}$

Because of the danger from these complications, repair of paraesophageal hernias is widely recommended soon after diagnosis. A detailed picture of the nature and behavior of these hiatal hernias at the population level is, however, lacking, with surgical decisions based on small studies and anecdotal case reports. ${ }^{8,9,13,14,18-21}$ The aim of our study was to evaluate population-based mortality from paraesophageal hernias in symptomatic patients and the nature of these lethal complications, including those occurring postoperatively, inside one clearly defined geographic area.

\section{MATERIALS AND METHODS}

Data for this study came from 2 Finnish administrative databases held by the National Research and Development Center for Welfare and Health and Statistics Finland. 


\section{Abbreviations and Acronyms \\ $\mathrm{CI}=$ confidence interval \\ GERD $=$ gastroesophageal reflux disease}

All hospitals in Finland licensed to perform operations must, annually, since January 1987, report every patient to the Central Registry held by National Research and Development Center for Welfare and Health. Each operation has a separate code (JBB 00, open operation for paraesophageal hernia; JBB 01, laparoscopic operation for paraesophageal hernia), including a diagnostic code (K44.0, hiatal hernia with incarceration; K44.1, hiatal hernia with gangrene; K44.9, hiatal hernia without incarceration or gangrene), so that all these procedures can be reliably identified in the National Research and Development Center for Welfare and Health database. This database provides the number of patients with paraesophageal hernias treated or operated on in Finland (population of approximately 5 million) between January 1987 and December 2001. Because those patients who die in the hospital of unknown causes are reported with their postmortem diagnosis (the overall rate of autopsies was $75 \%$ ), only the 3 patients in this study experiencing sudden death at home were not retrievable from this database. The number of patients hospitalized was compared with the number of deaths to estimate mortality from paraesophageal hernia in symptomatic patients requiring hospital treatment. Because of the unknown number of asymptomatic or even symptomatic nonhospitalized patients with paraesophageal hernias, the overall mortality of patients with this condition remains unclear.

The second database, held by Statistics Finland, provided data to evaluate mortality from paraesophageal hernia. All deaths in Finland must be reported to Statistics Finland with a death certificate including at least one diagnostic code. According to Statistics Finland, between January 1987 and December 2001, a total of 333 deaths occurred in which esophagitis, esophageal ulcer, esophageal stricture, hiatal hernia, or paraesophageal hernia was considered the primary, contributing, or immediate cause of death. The hospital and case records from these patients' primary health care physicians were obtained similarly. ${ }^{11}$ The following items were recorded: patient age and sex, medication, concomitant diseases, history of GERD, examinations and operations on the upper gastrointestinal tract, symptoms and treatment, and date and cause of death. The type of hiatal hernia was classified according to the present guidelines as described in the autopsy report or in medical records or by assessment of prior endoscopic or radiographic studies. ${ }^{3,4}$ By definition, all patients with paraesophageal hernias were included. Because the 301 patients excluded had no paraesophageal hernias, their cause of death was not pertinent. ${ }^{11,22}$

The final analysis of 333 possible patients provided 32 patients whose deaths were related to fatal complications of paraesophageal hernia. Their mean age was 72 years (range, 24-91 years), and male subjects numbered 12. Comorbid conditions were present in $29(91 \%)$ patients (Table 1). Four $(12.5 \%)$ patients had type II hiatal hernias. Type III hernias occurred in $16(50 \%)$ and type IV hernias occurred in $9(28.1 \%)$ patients. In $3(9.4 \%)$ patients the type of hiatal hernia was not stated. Of the 32 patients, 4 had a prior history of foregut or esophageal surgery. Two patients had undergone a laparoscopic Nissen fundoplication 35 days or 6 months, respectively, before death; 1 patient had undergone open hiatoplasty and gastropexy 8 years before death; and 1 had surgical intervention for esophageal stricture 10 years before death. For 32 patients, cause of death was defined together with clinical course and findings at autopsy in $24(75 \%)$ patients; it was based on clinical symptoms and prior workup in $7(22 \%)$ patients (radiographic studies, $\mathrm{n}=5$; endoscopy, $\mathrm{n}=2$ ). An emergency operation revealed the diagnosis in 1 patient.

Means, minimums, maximums, standard deviations, and 95\% confidence intervals (CIs) were the descriptive statistics. Statistical differences were calculated by using the $\chi^{2}$ or $t$ tests.
The study presented here was approved by the Ethics Committee of the Department of Surgery, Helsinki University Central Hospital, and by the Finnish Ministry of Social Affairs and Health.

\section{RESULTS}

Paraesophageal hernia was the cause of death from 1987 through 2001 in Finland (adult population, approximately 3.8 million) for 32 patients, resulting in an annual mortality of 0.6/1,000,000 adult inhabitants (95\% CI, 0-1.8/ $1,000,000)$. During the study period, Finnish hospitals reported 630 patients with paraesophageal hernias (annual mean, $42 \pm 7.7$; range, 32-62), with an annual rate of admission of 8.2/1,000,000 inhabitants (95\% CI, 6.2-12.1/ $1,000,000$ ) and with 782 (annual mean, $52 \pm 12.5$; range, 36-79) treatment periods. Of these 630 patients, 563 $(89 \%)$ underwent surgical treatment: $512(90.9 \%)$ open procedures and $51(9.1 \%)$ laparoscopic procedures. After elective repair of the paraesophageal hernia, 3 patients died. Overall, operative mortality was $2.7 \%(15 / 563) ; 12(2.3 \%)$ patients died after open $(\mathrm{n}=512)$ and $3(5.9 \%)$ after laparoscopic $(n=51)$ procedures. In-hospital mortality from conservative treatment in patients hospitalized during the study period for symptomatic paraesophageal hernia was $16.4 \%$ (11/67). Because of the unknown number of asymptomatic or even symptomatic nonhospitalized patients with paraesophageal hernias, overall mortality from conservative treatment remains unclear. In patients with a gangrenous stomach $(\mathrm{n}=90)$, the mortality rate was $10 \%$.

Of 29 patients with acute symptoms leading to death, 16 $(55 \%)$ had a known paraesophageal hernia before hospitalization (Table 1). Those who had 1 to several attacks of symptoms suggestive of obstruction or incarceration and requiring hospital treatment numbered 11 , with vomiting in 8 , and abdominal pain similar to the symptoms occurring before death in 2; 1 patient was hospitalized for severe dyspnea similar to symptoms she had experienced several times previously. The mean length of time these patients had been symptomatic was 42 months (range, 2-96 months). Four symptomatic patients might have had elective operations for paraesophageal hernia, the rate being $13 \%$ of the deaths (Table 1).

Causes of death are shown in Table 1. Of those 29 patients with acute symptoms leading to death, $25(86 \%)$ were given diagnoses of complicated paraesophageal hernia. Only $3(10 \%)$ died suddenly at home. The most common agonal symptoms were hematemesis (8 [28\%]), vomiting (7 [24\%]), abdominal pain $(6[21 \%])$, respiratory insufficiency $(3[10 \%])$, chest pain $(2[6 \%])$, fever and poor general condition $(2[6 \%])$, and nausea with constipation (1 [3\%]). Those considered unfit for surgical intervention because of poor general condition numbered 12. Among these 29 patients, those with a previously diagnosed paraesophageal hernia were more likely to have undergone emergency operations $(P=.010)$. Overall, no significant difference emerged in age $(70.0 \pm 12.0$ vs $75.1 \pm 16.8$ years, 
TABLE 1. Characteristics of patients dying from a paraesophageal hernia

\begin{tabular}{|c|c|c|c|c|c|}
\hline $\begin{array}{c}\text { Patient } \\
\text { no./sex/age (y) }\end{array}$ & $\begin{array}{l}\text { Comorbid } \\
\text { conditions }\end{array}$ & $\begin{array}{c}\text { Symptoms/previous } \\
\text { operation }\end{array}$ & $\begin{array}{c}\text { Suitable for } \\
\text { elective operation }\end{array}$ & $\begin{array}{l}\text { Emergency/urgent } \\
\text { treatment of hernia }\end{array}$ & Cause of death \\
\hline \multicolumn{6}{|c|}{ Patients with known paraesophageal hernias before their final hospitalization } \\
\hline $1 / \mathrm{F} / 82$ & Heart insufficiency & No & No & No & $\begin{array}{l}\text { Incarceration with } \\
\text { pneumonia }\end{array}$ \\
\hline $2 / \mathrm{M} / 85$ & CAD & No & No & No & $\begin{array}{l}\text { Incarceration with } \\
\text { bleeding }\end{array}$ \\
\hline $3 / \mathrm{M} / 70$ & Hypertension, AF, PE & No & No & Open fundoplication & $\begin{array}{l}\text { Incarceration with } \\
\text { obstruction and } \\
\text { pneumonia }\end{array}$ \\
\hline $4 / F / 67$ & Hypertension, sarcoidosis & $\begin{array}{l}\text { No/laparoscopic } \\
\text { fundoplication } 6 \mathrm{mo} \\
\text { previously }\end{array}$ & No & Gastrectomy & $\begin{array}{l}\text { Incarceration with gastric } \\
\text { gangrene and sepsis }\end{array}$ \\
\hline $5 / \mathrm{M} / 74$ & $\begin{array}{c}\text { Hypertension, AF, } \\
\text { prostate cancer }\end{array}$ & No & No & No & $\begin{array}{l}\text { Incarceration with } \\
\text { compression of IVC, } \\
\text { thrombosis of femoral } \\
\text { veins and PE }\end{array}$ \\
\hline $6 / F / 82$ & Dementia & Yes & No & No & Bleeding from hernia ulcer \\
\hline 7/M/68 & Asthma, COPD, dementia & Yes & No & No & $\begin{array}{l}\text { Incarceration with } \\
\text { bleeding and aspiration }\end{array}$ \\
\hline $8 / F / 38$ & Polyarteritis nodosa & Yes & Yes & $\begin{array}{l}\text { Gastric suturation, } \\
\text { reposition, and } \\
\text { hiatoplasty }\end{array}$ & $\begin{array}{l}\text { Incarceration with gastric } \\
\text { perforation with } \\
\text { resuscitation and } \\
\text { anoxic brain damage }\end{array}$ \\
\hline 9/F/81 & $\begin{array}{l}\text { Hypertension, asthma, } \\
\text { polymyalgia } \\
\text { rheumatica }\end{array}$ & Yes & No & $\begin{array}{l}\text { Laparoscopic } \\
\text { fundoplication }\end{array}$ & $\begin{array}{l}\text { Iatrogenic esophageal } \\
\text { perforation }\end{array}$ \\
\hline 10/F/71 & Motoric paraparesis & Yes & Yes? & Open fundoplication & $\begin{array}{l}\text { Iatrogenic esophageal } \\
\text { perforation }\end{array}$ \\
\hline $11 / \mathrm{F} / 81$ & Dementia & $\begin{array}{r}\text { Yes/unknown type for } \\
\text { esophageal stricture }\end{array}$ & No & $\begin{array}{l}\text { Open reposition and } \\
\text { hiatoplasty }\end{array}$ & $\begin{array}{l}\text { Incarceration with } \\
\text { pneumonia, } \\
\text { postoperative gastric } \\
\text { perforation }\end{array}$ \\
\hline $12 / \mathrm{M} / 66$ & CAD & Yes & Yes & Open fundoplication & $\begin{array}{l}\text { Incarceration with } \\
\text { obstruction and } \\
\text { pneumonia }\end{array}$ \\
\hline $13 / F / 59$ & $\mathrm{CAD}$, rheumatoid arthritis & Yes & Yes & Gastropexy & $\begin{array}{l}\text { Incarceration with } \\
\text { postoperative septic } \\
\text { shock }\end{array}$ \\
\hline $14 / F / 80$ & CAD, Parkinson's disease & Yes & No? & $\begin{array}{l}\text { Laparoscopic } \\
\text { fundoplication }\end{array}$ & Iatrogenic bleeding \\
\hline $15 / F / 91$ & - & Yes & No & No & $\begin{array}{l}\text { Incarceration with } \\
\text { obstruction }\end{array}$ \\
\hline $16 / F / 83$ & Heart insufficiency & Yes & No & $\begin{array}{l}\text { Open reposition with } \\
\text { hiatoplasty and } \\
\text { gastropexy }\end{array}$ & Postoperative heart failure \\
\hline \multicolumn{6}{|c|}{ Patients without previous diagnosis of paraesophageal hernia } \\
\hline $17 / \mathrm{M} / 85$ & CAD, dementia & & & Diagnosed at autopsy & $\begin{array}{l}\text { Incarceration with gastric } \\
\text { gangrene and bleeding }\end{array}$ \\
\hline $18 / \mathrm{F} / 89$ & Heart insufficiency & & & Diagnosed at autopsy & $\begin{array}{l}\text { Incarceration with cardiac } \\
\text { embarrassment }\end{array}$ \\
\hline 19/M/54 & Mental retardation & & & Diagnosed at autopsy & $\begin{array}{l}\text { Incarceration with } \\
\text { respiratory } \\
\text { embarrassment }\end{array}$ \\
\hline
\end{tabular}


TABLE 1. Continued

\begin{tabular}{|c|c|c|c|c|c|}
\hline $\begin{array}{c}\text { Patient } \\
\text { no./sex/age (y) } \\
\end{array}$ & $\begin{array}{l}\text { Comorbid } \\
\text { conditions } \\
\end{array}$ & $\begin{array}{c}\text { Symptoms/previous } \\
\text { operation }\end{array}$ & $\begin{array}{c}\text { Suitable for } \\
\text { elective operation }\end{array}$ & $\begin{array}{c}\text { Emergency/urgent } \\
\text { treatment of hernia }\end{array}$ & Cause of death \\
\hline $20 / F / 24$ & Asthma & $\begin{array}{l}\text { Laparoscopic } \\
\text { fundoplication } 1 \mathrm{mo} \\
\text { previously }\end{array}$ & & Diagnosed at autopsy & $\begin{array}{l}\text { Incarceration with gastric } \\
\text { gangrene }\end{array}$ \\
\hline $21 / \mathrm{M} / 75$ & CAD & & & Poor general condition & $\begin{array}{l}\text { Incarceration with } \\
\text { obstruction }\end{array}$ \\
\hline $22 / \mathrm{F} / 80$ & $\mathrm{CAD}$ & & & Poor general condition & $\begin{array}{l}\text { Incarceration with } \\
\text { respiratory } \\
\text { embarrassment }\end{array}$ \\
\hline $23 / \mathrm{F} / 66$ & $\begin{array}{l}\text { Heart insufficiency, } \\
\text { polyarteritis nodosa }\end{array}$ & & & Poor general condition & $\begin{array}{l}\text { Incarceration with gastric } \\
\text { gangrene and } \\
\text { perforation }\end{array}$ \\
\hline $24 / \mathrm{M} / 82$ & Parkinson's disease & & & Poor general condition & $\begin{array}{l}\text { Incarceration with gastric } \\
\text { gangrene and } \\
\text { perforation }\end{array}$ \\
\hline $25 / \mathrm{F} / 91$ & - & & & $\begin{array}{l}\text { High age and poor } \\
\text { condition }\end{array}$ & $\begin{array}{l}\text { Incarceration with } \\
\text { respiratory } \\
\text { embarrassment }\end{array}$ \\
\hline $26 / \mathrm{M} / 63$ & Alcoholism, hypertension & & & $\begin{array}{l}\text { Failed resuscitation before } \\
\text { operation }\end{array}$ & $\begin{array}{l}\text { Incarceration with } \\
\text { respiratory } \\
\text { embarrassment and } \\
\text { pneumonia }\end{array}$ \\
\hline $27 / F / 76$ & $\mathrm{PE}$ & & & $\begin{array}{l}\text { Hemicolectomy and } \\
\text { hiatoplasty }\end{array}$ & PE \\
\hline $28 / \mathrm{F} / 85$ & CAD & Hiatoplasty & & $\begin{array}{l}\text { Sengstake-Blakemore } \\
\text { tube }\end{array}$ & $\begin{array}{l}\text { Multiple hernia ulcers } \\
\text { with perforation and } \\
\text { bleeding }\end{array}$ \\
\hline \multirow[t]{2}{*}{$29 / \mathrm{F} / 77$} & Rheumatoid arthritis & & & Gastric resection & $\begin{array}{l}\text { Incarceration with gastric } \\
\text { necrosis and } \\
\text { perforation }\end{array}$ \\
\hline & $\begin{array}{l}\text { Complications of } \\
\text { elective operation }\end{array}$ & Indication for operation & & Type of operation & \\
\hline $30 / \mathrm{M} / 66$ & - & $\begin{array}{l}\text { Barrett's esophagus and } \\
\text { type III hernia }\end{array}$ & & Open fundoplication & Intestinal perforation \\
\hline $31 / \mathrm{F} / 57$ & $\begin{array}{l}\text { Heart insufficiency, } \\
\text { diabetes }\end{array}$ & $\begin{array}{l}\text { Erosive esophagitis, type } \\
\text { III hernia, and gastric } \\
\text { ulcer disease }\end{array}$ & & $\begin{array}{l}\text { Gastric resection with } \\
\text { vagotomy }\end{array}$ & $\begin{array}{l}\text { Leakage of enteral } \\
\text { anastomoses }\end{array}$ \\
\hline $32 / F / 78$ & COPD & $\begin{array}{c}\text { Nonerosive esophagitis } \\
\text { and type III hernia }\end{array}$ & & $\begin{array}{l}\text { Laparoscopic } \\
\text { fundoplication }\end{array}$ & $\begin{array}{l}\text { Pancreatitis with } \\
\text { multiorgan failure }\end{array}$ \\
\hline
\end{tabular}

$C A D$, Coronary artery disease; $A F$, atrial fibrillation; $P E$, pulmonary embolism; $I V C$, inferior vena cava; $C O P D$, chronic obstructive pulmonary disease.

$P=.340)$ or in the rate of comorbid conditions $(P=.621)$ between patients who underwent elective or emergency operations compared with those not undergoing operations. In the 15 surgical patients, indication for surgical intervention was incarceration of hiatal hernia, with esophageal obstruction in 6 patients, acute respiratory insufficiency in 2 patients, and acute tension gastrothorax, occlusion, peritonitis, and sepsis in 1 patient each. In 3 patients the indication for elective surgical intervention was symptomatic GERD with a type III hiatal hernia. The surgical approach was abdominal in 13 patients, 10 open and 3 laparoscopic procedures, but in 2 patients the approach was thoracoabdominal. For immediate cause of death among these 15 patients, see Table 1 .
Six deaths were considered to result from perioperative complications.

\section{DISCUSSION}

During the 15-year study period, paraesophageal hernia in Finland led to 32 deaths, resulting in an annual mortality of $0.6 / 1,000,000$ adult inhabitants. Of severely symptomatic patients, $16.4 \%$ died in the hospital after conservative treatment at a mean time of 42 months from onset of symptoms. Only 3 died after elective operations. It thus seems likely that the results of surgical intervention for paraesophageal hernia are better than expected, and at least low-risk patients, even with minimal symptoms, should therefore undergo elective operations. 
This annual rate of admission to the hospital of 8.2/ $1,000,000$ adult inhabitants is, to our knowledge, the first reported estimate of the prevalence of severely symptomatic paraesophageal hernia at the population level. Recently, the need for emergency surgical intervention was estimated to be low: $1.16 \%$ per year, with a lifetime risk of $18 \%$ at the age of 65 years. In our study $16.4 \%$ of patients with symptoms that require hospital treatment died at a mean time of 42 months. In a 1967 series of 21 patients presented by Skinner and Belsey ${ }^{3}$ of symptomatic patients treated medically, those who died as a result of complications of paraesophageal hernia numbered $6(28.6 \%)$. The high reported mortality from emergency surgery is the second reason for the general belief in the surgical community that paraesophageal hernia is a mandatory indication for surgical intervention. ${ }^{23-25}$ According to a recent review, mortality from emergency surgical intervention for paraesophageal hernia has been overestimated, ${ }^{7}$ and our results support those findings that the mortality from emergency surgical intervention is less than $10 \%$; this low mortality rate would suggest more conservative treatment among asymptomatic patients because many of them are old with comorbidities.

In the present study 4 patients had undergone a previous operation, including 2 laparoscopic fundoplications in the hiatal region. In most cases paraesophageal hernia after laparoscopic surgery has been asymptomatic. ${ }^{15,26}$ It has even been suggested that paraesophageal hernias occurring after laparoscopic foregut surgery should be considered a distinct entity, differing from de novo paraesophageal hernias. ${ }^{26}$ Sometimes these hernias are, however, associated with life-threatening complications, such as a fistula between the pericardium and stomach. ${ }^{27}$ Furthermore, our results indicate that these hernias also show a potential for catastrophic consequences.

A study by Hoffman ${ }^{8}$ found incarceration of a hiatal hernia or gastric volvulus occurring mostly in those patients with a true paraesophageal hernia. Conversely, most patients $(78 \%)$ in our study had either type III or IV hernias, with a true paraesophageal hernia detectable in only $14 \%$. This is in accordance with the findings of Pearson and colleagues. ${ }^{9}$ All our fatalities were related either to incarceration or to gastric volvulus, with presenting symptoms of gastric obstruction, gastric gangrene, or hemorrhage. In this type of rare medical emergency, diagnostic accuracy was relatively high: only 3 patients died at home. In addition, rare complications, such as acute tension gastrothorax or heart failure, make diagnosis of a complicated paraesophageal hernia difficult. ${ }^{16,17}$

Although retrospective studies based on administrative data always have limitations, data on health-resource use in Nordic countries like Finland are generally considered reliable. From our Death Registry, with its wide range of esophageal diseases, we tried to retrieve all possible cases for preliminary analysis. Although the clinical accuracy of any administrative database can always be questioned, these provide good preliminary data for population-based studies. All preliminary cases could be evaluated by retrieval of all hospital records. Adding to our clinical data's reliability is the high rate of autopsies performed (ie, $71 \%$ ).

In conclusion, fatal complications of paraesophageal hernia were rare, mostly related to type III or IV hernias in aged patients with concomitant diseases. In these patients high surgical risk and overestimated mortality in emergency operations for paraesophageal hernia support the concept of watchful conservative treatment. With this policy, because most of our patients were old with concomitant diseases or because the actual presence of a hernia remained unknown, only a small number of deaths $(12.5 \%)$ might have been prevented by elective surgical intervention. To expect to reduce the number of deaths further would require performing operations in patients at higher surgical risk. Based on our results, repair of paraesophageal hernia, at least in symptomatic patients, can be recommended, except for those with an estimated mortality risk of more than $10 \%$ in elective surgical intervention.

We thank Yvonne Sundström for skillful secretarial assistance.

\section{References}

1. Dent J, El-Serag H, Wallander M, Johansson S. Epidemiology of gastro-oesophageal reflux disease: a systematic review. Gut. 2005;54:710-7.

2. Berstad A, Weberg R, Froyshov Larsen I, Hoel B, Hauer-Jensen M. Relationship of hiatus hernia to reflux oesophagitis. A prospective study of coincidence, using endoscopy. Scand J Gastroenterol. 1986;21:55-8.

3. Skinner DB, Belsey RH. Surgical management of esophageal reflux and hiatus hernia: long-term results with 1,030 patients. J Thorac Cardiovasc Surg. 1967; $53: 33-54$

4. Duranceau A, Lafontaine E. The esophagus. In: Sabiston DC Jr, ed. Sabiston's essentials of surgery. Philadelphia: Saunders; 1987:363-87.

5. Allen MS, Trastek VF, Deschamps C, Pairolero P. Intrathoracic stomach. Presentation and results of operation. J Thorac Cardiovasc Surg. 1993;105:253-9.

6. Hallissey MT, Ratliff DA, Temple JG. Paraoesophageal hiatus hernia: surgery for all ages. Ann R Coll Surg Engl. 1992;74:23-5.

7. Stylopoulos N, Gazelle GS, Rattner DW. Paraesophageal hernias: operation or observation? Ann Surg. 2002;236:492-501.

8. Hoffman E. Strangulated diaphragmatic hernia. Thorax. 1968;23:541-9.

9. Pearson FG, Cooper JD, Ilves R, Todd TR, Jamieson WR. Massive hiatal hernia with incarceration: a report of 53 cases. Ann Thorac Surg. 1983;35:45-51.

10. Simoens C, Verschakelen JA, Ponette E, Baert AL. Gastric volvulus as a complication of a left superior lobectomy in a patient with pre-existing hiatal hernia. J Belge Radiol. 1994;77:164-5.

11. Rantanen TK, Sihvo EI, Räsänen JV, Salo JA. Gastroesophageal reflux disease as a cause of death is increasing: analysis of fatal cases after medical and surgical treatment. Am J Gastroenterol. 2007;102:246-53.

12. Rantanen, Salo JA. Gastroesophageal reflux disease as a cause of death: analysis of fatal cases under conservative treatment. Scand J Gastroenterol. 1999;34 229-33.

13. Salling N, Falensteen AM, Larsen LG. Non-traumatic perforation of gastric ulcer in a hiatal hernia to the pericardium. Acta Med Scand. 1983;213:225-6.

14. Cathcart RS 3rd, Gregorie HB, Holmes SL. Nonreflux complications of hiatal hernia. Am Surg. 1987;53:320-4.

15. Hashemi M, Sillin LF, Peters JH. Current concepts in the management of paraesophageal hiatal hernia. J Clin Gastroenterol. 1999;29:8-13.

16. Hunt GS, Gilchrist DM, Hirji MK. Cardiac compression and decompensation due to hiatus hernia. Can J Cardiol. 1996;12:295-6.

17. Tadler SC, Burton JH. Intrathoracic stomach presenting as acute tension gastrothorax. Am J Emerg Med. 1999;17:370-1. 
18. Boyd EJ, Penston JG, Russell RI, Wormsley KG. Hiatal hernia ulcers: clinical features and follow-up. Postgrad Med J. 1991;67:900-3.

19. Brullet E, Campo R, Combalìa N, Marques G, Armengol-Miro JR. Gastric ulcer perforation into the heart. Endoscopy. 1996;28:316-8.

20. Oosterbosch L, Vandebroek A, Holvoet J, Vaerenberg M, Nagler J. Benign ulcer in a hiatus hernia complicated with a pericardial fistula. Acta Gastroenterol Belg. 1996;59:248-50.

21. Riepe G, Braun S, Swoboda L. Die Perforation ins Herz-seltene Komplikation eines Ulcus ventriculi in einer Hiatushernie. Chirurg. 1998;69:475-6.

22. Sihvo EIT, Rantanen TK, Räsänen JV, Hynninen M, Salo JA. Esophageal ulcer as a cause of death: a population-based study. Dig Dis. In press.
23. Hill LD. Incarcerated paraesophageal hernia. A surgical emergency. Am J Surg. 1973;126:286-91.

24. Harriss DR, Graham TR, Galea M, Salama FD. Paraesophageal hiatal hernias: when to operate. J R Coll Surg Edinb. 1992;37:97-8.

25. Cloyd DW. Laparoscopic repair of incarcerated paraesophageal hernias. Surg Endosc. 1994;8:893-7.

26. Mattar SG, Bowers SP, Galloway KD, Hunter JG, Smith CD. Long-term outcome of laparoscopic repair of paraesophageal hernia. Surg Endosc. 2002;16:745-9.

27. Sihvo EI, Rasanen JV, Hynninen M, Rantanen TK, Salo JA. Gastropericardial fistula, purulent pericarditis and cardiac tamponade after laparoscopic Nissen fundoplication. Ann Thorac Surg. 2006;81:356-8. 